\title{
Socjolekty w edukacji szkolnej (propozycja dydaktyczna na przykładzie języka miłośników motoryzacji)
}

\author{
Sociolects in school education \\ (didactic proposal \\ on the example of the language of automotive enthusiasts)
}

Summary: The article concerns the issue of community languages, i.e. sociolects. The text is a didactic proposal for Polish language lessons, especially for the seventh and eighth grades of the second educational stage. In addition to the characteristics of the issue, the author presents sets of tasks (of varying degrees of difficulty), in which she uses analytical material concerning the automotive sociolect. In the language of automotive enthusiasts, the lexical field which reflects technical changes and the development of society is growing.

Keywords: sociolect, the language of automotive enthusiasts, Polish language lesson, community language varieties

\section{Wprowadzenie}

Ze zróżnicowaniem polszczyzny uczeń styka się od najmłodszych lat zarówno w kontekście edukacyjnym, jak i w codziennym życiu. Świadomość niejednorodności używanego języka w różnych okolicznościach komunikacyjnych powinna być w edukacji polonistycznej wzmacniana i kształtowana. Ważnym jej aspektem jest dostosowanie języka do konkretnej sytuacji komunikacyjnej, co bezsprzecznie wpływa na skuteczność komunikacji. 
W podstawie programowej przewidzianej dla drugiego etapu edukacyjnego czytamy w punkcie II.2.5, że uczeń ,wyróżnia środowiskowe i regionalne odmiany języka"1. Moja propozycja dotyczy pewnej koncepcji przeprowadzenia w szkole podstawowej lekcji z zakresu socjolektów. Wątki teoretyczne zostały wzbogacone pytaniami praktycznymi, aktywizującymi ucznia w czasie zajęć, a także zbiorem ćwiczeń do wykorzystania w wersji przedstawionej lub zmodyfikowanej w trakcie lekcji. Zaprezentowany pomysł zajęć i proponowane zadania mogą być adresowane do końcowych klas drugiego etapu edukacyjnego (VII-VIII klasa). Stopień trudności zadań jest zróżnicowany (ćwiczenia zostały przedstawione w artykule zgodnie ze wzrastającą skalą trudności). Propozycja może stanowić samodzielną lekcję poświęconą socjolektom, może być również elementem cyklu lekcji (ze względu na konkretny materiał źródłowy język miłośników motoryzacji ${ }^{2}$, alternatywnymi socjolektami mogą być socjolekty uczniowski/młodzieżowy). O swoistości socjolektu uczniowskiego i możliwości jego wykorzystania do kształtowania świadomości językowej uczniów pisała Jadwiga Kowalikowa:

Szkolny pejzaż komunikacyjny niewątpliwie ubarwia gwara uczniowska. Rozwijając się w założeniach jako rodzaj języka tajnego, pojawia się przede wszystkim w sytuacjach nieoficjalnych w ramach interakcji między

${ }^{1}$ Zob. Podstawa programowa ksztatcenia ogólnego dla przedszkoli i szkót podstawowych $z$ komentarzem. https://www.ore.edu.pl/wp-content/uploads/2017/05/jezyk-polski.-pp-z-komentarzem.-szkola-podstawowa.pdf [data dostępu: 26.02.2019]. Przy okazji zastosowania przedstawionej propozycji na lekcji dodatkowo będą realizowane następujące punkty podstawy: ,[...] posługuje się oficjalną i nieoficjalną odmianą polszczyzny [...]" (II.2.2, Treści nauczania — wymagania szczegółowe, klasa IV—VI); „[...] dostosowuje sposób wyrażania się do zamierzonego celu wypowiedzi” (II.2.7, Treści nauczania — wymagania szczegółowe, klasa IV—VI); „[...] określa sytuację komunikacyjną i rozumie jej wpływ na kształt wypowiedzi” (II.3.3, Treści nauczania wymagania szczegółowe, klasa IV—VI); ,[...] korzysta ze słowników ogólnych języka polskiego, także specjalnych, oraz słownika terminów literackich" (IV.5, Treści nauczania — wymagania szczegółowe, klasa IV-VI); ,[...] dostrzega zróżnicowanie słownictwa, w tym rozpoznaje słownictwo ogólnonarodowe i słownictwo o ograniczonym zasięgu [...]” (II.2.1, Treści nauczania wymagania szczegółowe, klasa VII-VIII).

2 Język miłośników motoryzacji, określany także jako socjolekt motoryzacyjny, stanowi społeczną odmianę języka. Niejednorodność terminologiczna powoduje multiplikację określeń stosowanych do poszczególnych odmian języka. Wątpliwości dotyczące terminu ,,język” w odniesieniu do uwarunkowanych społecznie wariantów języka przedstawia Anna Wileczek, stwierdzając, że choć ,użycie terminu język bywa uzasadniane zwykle kryterium komunikacyjności [...], to wątpliwość budzi jednak, co podkreśla Aleksander Wilkoń [...], konotacja związana z ekspozycją znaczenia systemowości (język) i przestrzennego zamknięcia (gwara), do których większość wskazanych rejestrów nie aspiruje" (A. Wileczek: Kod młodości. Młodomowa w kontekstach społeczno-kulturowych. Warszawa 2018, s. 71). Mając świadomość ograniczeń terminologicznych, z powodów funkcjonalnych i stylistycznych będę w artykule wymiennie używać terminów: ,język miłośników motoryzacji”, ,,socjolekt motoryzacyjny”. 
młodzieżą. Dzięki swej wyrazistości w wyniku nacechowania ekspresją i humorem nie tylko pojawia się w sytuacji oficjalnej, np. na lekcji, lecz niekiedy przenika również do środowiska nauczycieli. [...] mogą one [dwie wymienione odmiany - W.W.] stanowić obiecujący przedmiot badań. Szczególnie upomina się o nie dynamiczna, zmieniająca się w swej warstwie leksykalnej, gwara uczniowska³ .

Ten postulat znalazł odzwierciedlenie w obowiązującej podstawie programowej.

\section{Ćwiczenie wstępne}

Sytuację motywacyjno-problemową lekcji mogłoby stanowić przedstawienie uczniom kilku krótkich fragmentów tekstów realizujących pewną socjolektalną odmianę języka — np. języka miłośników psów, graczy komputerowych. Zespół uczniowski można podzielić na grupy, z których każda otrzyma jeden przykład. Zadaniem uczniów byłoby przeczytanie i przeanalizowanie tekstów. Powinni wtedy zauważyć różnice językowe między próbkami — wskazać wyrazy, które dotycząokreślonego pola tematycznego, inazwać grupęosób, która siętakimsłownictwem posługuje. Celem zadania staje się ćwiczenie umiejętności rozpoznawania i charakterystyki danej odmiany języka środowiskowego.

Oto przykładowe teksty do wykorzystania (fragmenty rozmów z forów internetowych $\left.{ }^{4}\right)$ :

1. Socjolekt graczy komputerowych.

- Ale byt jeden poważny problem... Już w becie co 3,4 mecz byt gość $z$ aimbotem. Także jeśli już na becie sq cheaty, to nie wróże dobrej przyszłości tej grze.

$[\ldots]$

- Najjaśniejszym punktem tej gry natomiast jest moim zdaniem świetny tryb War, w który naprawde grało mi się przyjemnie, szkoda tylko, że, znając społeczność Coda, nikt nie będzie w niego grat po premierze, tylko w kółko w nudnego, powtarzalnego, i ciągle takiego samego TDM, więc

3 J. Kowalikowa: Jak się mówi i pisze w szkole? Szkic do pejzażu dydaktycznego szkolnych odmian jezzykowych. W: Odmiany polszczyzny w szkole. Teoria i praktyka. Red. H. Synowiec. Współudział M. Kubarek. Katowice 2013, s. 20.

${ }^{4}$ Przykłady zostały przytoczone z zachowaniem oryginalnej pisowni, bez poprawy błędów literowych, interpunkcyjnych itd., co w większym stopniu równocześnie uwydatnia specyfikę komunikacji internetowej. 
kupno gry tylko dla tego trybu nie ma żadnego sensu@ . A nawet jeśli by byt grany to pewnie zabawe zepsuja szybko bugi, quickscoperzy, campery, cheaterzy, czy inni oszuści wykorzystujacy glitche.

$[\ldots]$

- Patrzac po reckach na sztim chyba daleko mi bedzie do kupna gry na premiere ${ }^{5}$.

2. Socjolekt miłośników psów.

- Whippety sa urocze no i ... nie maja podszerstka. Pytanie tylko jak z linieniem u psów, które podszerstka nie mają?

$[\ldots]$

- obecnie mam w domu buldożka i sypia się z niego igiełki jak diabli. Jak $w$ whipetami to nie wiem.

$[\ldots]$

- pewnie podobnie nie ma co oszukiwać i łudzić, że sie nie będzie sypało, choćby okresowo... znam póki co tylko jedna rasę ktora prędzej sie zafilcuje niz cos z psa spadnie na podtoge, sa to Briardy... ${ }^{6}$.

3. Socjolekt miłośników gór.

- Nawet na szczytach nie było widać śniegu. Nawet nie brałem stuptutów, mimo że na V. Krivanu jest śnieg.

$[\ldots]$

- Na szczyt Rozsutca wejść się da-aczkolwiek warunki już trudniejsze (pokrywa nie do końca zwiąana w zwiazku z czym aktualnie jest 3 lawinowa) - pod śniegiem lód, dość ślisko - wymagane raki i dziaba, widoki na szczycie kiepskie (spore zachmurzenie).

$[\ldots]$

- Przypaliteś się na Fatrę widzę Masz już trasę zaplanowaną?7.

4. Socjolekt rowerzystów.

- Jako ze mam lekko za duża rame bo 21, a mój wzrost to $189 \mathrm{~cm}$, wiec powinienem miec 20 cale, to zastanawiam sie nad wymiana ramy pod bardziej agresywne tereny $i$ wieksza zwinnosc, doradzono mi firme dartmoor $i$ rame primal bądź hornet $[. .$.$] .$

$[\ldots]$

\footnotetext{
${ }^{5} \mathrm{https}: / /$ lowcygier.pl/forum/viewtopic.php?f=11\&t=17112 [data dostępu: 3.03.2019].

${ }^{6} \mathrm{https}$ ://www.dogomania.com/forum/topic/27154-jak\%C4\%85-ras\%C4\%99-mam-wy bra\%C4\%87-vol-2/?page $=607$ [data dostępu: 3.03.2019].

${ }^{7} \mathrm{http} / / /$ www.e-gory.pl/forum/viewtopic.php? $\mathrm{f}=17 \& \mathrm{t}=2178$ [data dostępu: 3.03.2019].
} 
- Będzie bardziej zwrotna, z niższym przekrokiem i ciagle dajaca przyjemność z podjeżdżania, jednak z powodu krótszej bazy kół może być nieco mniej stabilna przy dużych prędkościach.

[...]

- Czyli jakas rama lzejsza/lepsza/wytrzymalsza - skoro taki hardkorowiec ze mnie hehe, a reszta sprzetu zostaje, amor 100mm wystarczajacy, ogarne powietrze w nim bo SAG jest zbyt duzy, duzo wbija, zbyt duzo, co przeszkadza, choc moze na agresywnych zjazdach pomagalo ${ }^{8}$.

5. Socjolekt kibiców piłki nożnej.

— to Firmino teraz zagrywat te piłke prostopadta? Ależ niewiele zabrakto, byłaby kapitalna asysta...

$[\ldots]$

- Uwielbiam patrzeć jak przeciwnik Realu ma ewidentna przewage której nie jest w stanie przetożyć na bramki. Znając życie dostana ze dwie lepy z kontry $i$ będzie po zawodach.

[...]

- Teraz wszystko w rękach Kloppa, jak wykorzystat te 15 minut. Liverpool do kontuzji Salaha gniótt Real. Potem wszystko się posypało i cała gra $w$ ataku opiera się na Mane. Jeśli Liverpol wyjdzie zmotywowany jak przed meczem, to maja szansę. Jeśli nie, to Real będzie cierpliwy i w końcu cośs strzeli ${ }^{9}$.

\section{Socjolekty — charakterystyka}

Po krótkim wprowadzeniu należy zwrócić uwagę uczniów na różne czynniki determinujące zróżnicowanie polszczyzny. Wśród nich można wymienić między innymi: zasięg geograficzno-terytorialny języka (język ogólny, dialekty, regionalizmy), sposób przekazywania komunikatu językowego (mówiony/pisany), sytuację komunikacyjną (oficjalną/nieoficjalną), zakres tematyczny wypowiedzi (ogólny/specjalistyczny), charakterystykę socjalną uczestników komunikacji językowej (wiek, płeć, wykształcenie, miejsce zamieszkania

\footnotetext{
${ }^{8} \mathrm{http}: / /$ www.bikeforum.pl/topic/31834-czy-jest-sens-wymieniac-rame-a-moze-tylko -mostek-xc-ala-szybka-hybryda-enduro/ [data dostępu: 3.03.2019].

${ }^{9} \mathrm{http} / / /$ swiatpilki.com/viewtopic.php?f=8\&t=20692\&start=45; http://swiatpilki.com/viewtopic.php?f $=8 \& \mathrm{t}=20692 \&$ start $=90$ [data dostępu: 3.03.2019].
} 
itp. ${ }^{10}$. Uczeń z pewnością ma świadomość używania innego typu języka w szkole i w domu, podczas komunikacji z rówieśnikami i w trakcie przygotowywania wypracowań czy innych prac domowych. Wie, że innym językiem posługuje się $\mathrm{w}$ rozmowie $\mathrm{z}$ nieznajomymi, a innym $-\mathrm{z}$ kolegami; inaczej rozmawia $\mathrm{z}$ kilkuletnim dzieckiem, a w inny sposób komunikuje się z osobami dorosłymi. Do werbalizowania tych różnic, podyktowanych wskazanymi czynnikami, można uczniów zachęcić w trakcie lekcji, wzbogacając tym samym świadomość niejednorodności współczesnej polszczyzny oraz wiedzę na temat wielości komponentów wpływających na komunikację.

Wzbogacanie wiedzy o socjolektach jako środowiskowych odmianach polszczyzny warto rozpocząć od samego ich umiejscowienia pośród odmian polszczyzny. Tomasz Piekot twierdzi, że „Socjolekt [...] przekazuje pewien ujednolicony sposób odczuwania świata"11.

Zgodnie z konstatacją Stanisława Grabiasa

Kształtowanie się wewnętrznych odmian języka narodowego uwarunkowane jest działaniem czynników, które w zasadzie dają się opisywać w kategoriach zjawisk terytorialnych (gwary ludowe), funkcjonalnych (style) i społecznych. Dominujący wpływ czynników społecznych uzewnętrznia się w tzw. socjolektach: odmianach języka powstałych we wspólnotach wyznaczonych pewnym rodzajem więzi społecznej ${ }^{12}$.

Samo pojęcie „socjolekty” do polskiego językoznawstwa wprowadził Aleksander Wilkoń, wyróżniając ich wąski i szeroki zakres. Pierwszy z nich zdefiniował z punktu widzenia socjolingwistyki jako „ekspresywne lub/i zawodowe odmianki społeczne, czyli tzw. gwary środowiskowe i zawodowe, takie jak gwara złodziejska, gwara uczniowska czy gwara żołnierska"13. Znaczenie szerokie korelowało z przytoczoną już definicją:, ,[...] to odmiany językowe związane z grupami społecznymi, takimi jak klasa, warstwa, środowisko i grupy zawodowe [...]"14. Stanisław Grabias wyróżnia w swojej pracy Język w zachowaniach społecznych trzy podstawowe kategorie, dzięki którym można dokonać pewnej klasyfikacji socjolektów. Są to: zawodowość, ekspresywność i tajność (kodowanie informacji). Pierwsza z kategorii — zawodowość — odnosi się do przewagi słownictwa związanego z zawodowymi realiami grupy nad leksyką dotyczącą

${ }^{10}$ Zob. R. Przybylska: Wprowadzenie do nauki o języku polskim. Podręcznik dla szkót wyższych. Kraków 2003, s. 47.

${ }^{11}$ T. Piekot: Język w grupie społecznej. Wprowadzenie do analizy socjolektu. Wałbrzych 2008, s. 32.

${ }^{12}$ S. Grabias: Język w zachowaniach społecznych. Lublin 1997, s. 111.

13 A. Wilkoń: Typologia odmian językowych wspótczesnej polszczyzny. Katowice 2000, s. 87.

${ }^{14}$ Ibidem, s. 88. 
człowieka w ogóle. Socjolekty dotyczące profesjonalnych sfer działalności grupy społecznej cechują się wysokim stopniem zawodowości. W przypadku ekspresywności sytuacja jest odwrotna - socjolekty zawodowe są nieekspresywne, natomiast $\mathrm{w}$ socjolektach niezawodowych można zaobserwować znaczny stopień ekspresywności. Ostatnia ze wskazanych kategorii — tajność — dotyczy możliwości kodowania informacji, co tym samym zawęża krąg jej odbiorców. Można w ten sposób wyróżnić socjolekty intencjonalnie tajne (tajność wynikająca z realiów grupy, np. żargon przestępczy; tajność zabawowa, np. tajny język dzieci) i socjolekty intencjonalnie jawne (szeroka komunikatywność, np. slang młodzieżowy; wąska komunikatywność, np. język łowiecki) ${ }^{15}$. Badacze zwracają także uwagę na niejednorodność terminologiczną dotyczącą odmian języka - np. ,socjolekt”, ,gwara”, ,żargon”, „slang”"16. W ramach lekcji istotne będzie rozróżnienie na „socjolekty” (więź społeczna) i „profesjolekty” (więź zawodowa). Taki podział, motywowany profesją jako czynnikiem powstania danej odmiany języka, uwzględniają także inni badacze. Ewa Kołodziejek, która analizowała różne odmiany socjolektalne, uznaje, że profesjolekt realizuje wszystkie właściwości socjolektu, a jego elementem dodatkowym jest więź zawodowa ${ }^{17}$.

Należy również podkreślić funkcje socjolektów: łączenie jednostki ze zbiorowością (funkcja jednocząca); przeciwstawianie wyodrębnionej zbiorowości innym grupom społecznym (funkcja odróżniająca); posiadanie wysokiej rangi grupy w życiu wspólnoty komunikatywnej (funkcja nadawania prestiżu) oraz kreowanie rzeczywistości za pośrednictwem socjolektu (funkcja dostarczania narzędzi służących interpretowaniu rzeczywistości) ${ }^{18}$. Budowanie wspólnoty przez użytkowników danej socjolektalnej odmiany języka wydaje się najistotniejszym wyznacznikiem przynależności do grupy. W kolejnej fazie lekcji uczniowie mogliby wskazać przykłady profesjolektów (np. język lekarzy, prawników) oraz socjolektów (np. język miłośników zwierząt, amatorów jazdy konnej, pasjonatów gier wideo). Różnorodność przywołanych odmian może być pretekstem do zastosowania ćwiczeń i zabaw dramowych na temat konkretnego języka środowiskowego.

15 Zob. S. Grabias: Język w zachowaniach spolecznych..., s. 146-159.

${ }_{16}$ Zob. T. Piekot: Język w grupie spotecznej..., s. 29-32.

17 Zob. E. Kołodziejek: Społeczne i kulturowe uwarunkowania wspótczesnych odmian zawodowych (na przykladzie profesjolektów marynarzy, żolnierzy i policjantów). W: Polskie języki. O językach zawodowych i środowiskowych. Red. M. Milewska-Stawiany, E. Rogowska-Cybulska. Gdańsk 2010, s. 106.

18 Zob. ibidem, s. 135-136. 


\section{Socjolekt motoryzacyjny — ćwiczenia praktyczne}

Wielość odmian środowiskowych polszczyzny jest zbiorem niejednorodnym, z uwagi na zmiany społeczne - wciąż się powiększającym. Przykładem wykorzystanym na lekcji, obrazującym socjolektalne odmiany współczesnej polszczyzny, stał się socjolekt motoryzacyjny ${ }^{19}$. Tematyka motoryzacyjna stanowi nieodłączny element współczesnych rozmów, co świadczy o ekspansji technicznej i zaawansowanym rozwoju technologii motoryzacyjnych w rzeczywistości XXI wieku. Zgodnie z twierdzeniem Cezarego Szczepaniaka

samochód, który pojawił się pod koniec XIX wieku, jest dzisiaj w powszechnym użytku. Związki tego samochodu z jego właścicielem często wielokrotnie przekraczają racjonalne odniesienia człowieka do ziemskich, niematerialnych przedmiotów. Samochód jest dzisiaj czynnikiem w wielu przypadkach oddziałującym istotnie na codzienność mieszkańców Ziemi ${ }^{20}$.

Stale powiększająca się liczba samochodów na polskich drogach, w gospodarstwach domowych, a także ich obecność w przestrzeni medialnej — np. w reklamach konkretnych aut — powoduje upowszechnienie sfery motoryzacyjnej także w zakresie leksyki. W dalszej części artykułu przedstawiam kilka wybranych ćwiczeń, które można wykorzystać w głównej fazie lekcji.

Zadanie 1. Pozytywne, negatywne i neutralne określenia pojazdów. Pierwszy typ zadania może dotyczyć leksyki nazywającej pojazdy, związanej z pozytywnym, negatywnym lub neutralnym ich określaniem. Zadanie ma na celu zapoznanie uczniów ze słownictwem używanym przez miłośników motoryzacji. Wprowadza także kategorię wartościowania — poszczególne leksemy mogą być przedmiotem pozytywnej lub negatywnej waloryzacji pojazdu. Formą ćwiczenia będzie tabela 1 . grupująca trzy wymienione typy określeń.

${ }_{19}$ Przykłady analityczne (np. leksemy) i niektóre obserwacje zostały zaczerpnięte z książki mojego autorstwa: W. Wilczek: Polski język motoryzacyjny poczatku XXI wieku (na materiale portali hobbystycznych). Katowice 2016 . W związku z całościowym wskazaniem źródła, pominę każdorazowe odwoływanie się do konkretnej strony pracy. Jest to podyktowane przede wszystkim faktem, że moim celem nie jest zreferowanie przykładowych elementów socjolektu motoryzacyjnego, ale ich wykorzystanie w praktycznych ćwiczeniach na lekcjach języka polskiego. W przytoczonej pracy przedmiotem oglądu był język miłośników motoryzacji, odtworzony na podstawie portali motoryzacyjnych, obrazujących aktualny stan języka i wskazujących możliwe tendencje rozrostu pola leksykalnego.

${ }^{20}$ C. Szczepaniak: Zrozumieć samochód. Samochód bez tajemnic. Łódź 2011, s. 13. 
Tabela 1.

Pozytywne, negatywne i neutralne nazwy pojazdów

\begin{tabular}{|l|l|l|}
\hline Określenia pozytywne & Określenia negatywne & Określenia neutralne \\
\hline & & \\
\hline
\end{tabular}

Ćwiczenie może być wykonywane na dwa sposoby, zróżnicowane ze względu na stopień trudności. Pierwszą propozycją jest rozsypanka wyrazowa, zawierająca losowo dobrane leksemy z trzech wskazanych grup. Drugi sposób to samodzielne wskazywanie przez uczniów wyrazów (np. wraz z otrzymanym następnie mniejszym zbiorem wyrazów do posegregowania).

Przykładowe wyrazy do użycia w zadaniu to np.:

fura, zamulacz, gruchot, bryka, grat, rakieta, kanciak, ślicznotka, wehikut, cztery kółka, staroć, złom, auto, perełka, skarbonka, limuzyna, strzała, dziad, skarb, rupieć, śmietnik, auteczko, wyrób samochodopodobny, cacko, kloc, gniot, egzemplarz, rumak, zdechlak, maleństwo.

Dodatkową grupą wyrazów może być zbiór określeń zebrany w kolejnej kolumnie tabeli 1., skategoryzowany jako przeznaczenie pojazdu. W jego zakres mogą wejść np. leksemy mieszczuch (do jazdy w mieście, samochód miejski), wózek na zakupy, zakupowóz (samochód przeznaczony na zakupy, np. z pojemnym bagażnikiem), driftowóz, wózek sportowy (samochód ze sportowym przeznaczeniem; drift - jazda samochodem w kontrolowanym poślizgu), wycieczkowóz, turystyk (pojazd przeznaczony na wyjazdy turystyczne).

Zawartość poszczególnych grup - po podliczeniu - winna doprowadzić do wniosku o znaczącej przewadze nazw wartościowanych pozytywnie lub negatywnie nad nazwami neutralnymi. Świadczy to o ekspresywności używanych określeń, emocjonalnym nastawieniu do pojazdu, eksponowaniu pewnych cech, a także o kontekstowym użyciu wielu zaprezentowanych wyrazów (auteczko może być pieszczotliwym określeniem samochodu, ale może także ironicznie nawiązywać do niewielkich rozmiarów pojazdu). Grupowanie wyrazów może być wzbogacone wskazywaniem podstawy wartościowania, np. leksemy odnoszące się do wyglądu samochodu (kanciak, kloc), jego stanu technicznego (rupieć, grat), wieku pojazdu (staroć), nowoczesności i wyjątkowości (skarb, cacko), jego szybkości (rakieta, strzała), konieczności dużych nakładów finansowych (skarbonka).

Dodatkowym działaniem lekcyjnym może być układanie zdań z wybranymi z tabeli określeniami, co wzmocni świadomość ich znaczenia i kontekstowego użycia. W tym miejscu warto również przeprowadzić ćwiczenia polegające na napisaniu przez uczniów tekstu $\mathrm{z}$ określeniami (np. ogłoszenia motoryzacyjnego, które pisze pasjonat motoryzacji). $Z$ jednej strony będzie to realizacja 
ważnej w edukacji uczniów formy wypowiedzi, jaką jest ogłoszenie; z drugiej natomiast - określenia potoczne zastosowane w tekście uzmysłowią i zobrazują proces budowania wspólnoty wśród miłośników samochodów (użycie leksyki pozwalającej na lepsze dotarcie do potencjalnych nabywców samochodu).

Zadanie 2. Animizacja i antropomorfizacja pojazdów. Wstępem do ćwiczenia będzie przypomnienie/przywołanie pojęć ,,animizacja” oraz „,antropomorfizacja". Bazę ćwiczenia mogą stanowić przykładowe zdania lub krótkie teksty, w których zawarte będą animizowane bądź antropomorfizowane wyrazy/wyrażenia. Zadaniem uczniów będzie odnalezienie w tekście wyrazów i zaklasyfikowanie ich do odpowiednich pól leksykalnych oraz wskazanie funkcji używania takiej leksyki. Oto przykładowe zdania (wraz z podanym rozwiązaniem, wskazanym pogrubieniem):

Moja bryka pije 9 litrów benzyny na mieście. Naprawdę ma apetyt na paliwo - prawdziwy olejożłop! To auto czasem miewa dolegliwości, ale zawsze dojedzie do celu. Mogę na nim polegać. Blacha jest w nim stu procentach zdrowa.

Auto jeździ, ale jest mocno zmęczone i ma jakieś choroby, czasami kaszle przy odpalaniu i brakuje mu tchu przy większych prędkościach. Poza tym je duzo paliwa. Jestem jednak do niego bardzo przywiazany. A czy wasze auta sq zdrowe, czy coś je boli? I czy tak smakuje im paliwo?

Mój pojazd jest w stabej kondycji, ostatnio trochę chorowat $i$ musiatem go reanimować u mechanika. Teraz bywa czasem umęczony, ale nie chce go katować dtugimi trasami, bo miewa zadyszkę. Żtopie też dużo paliwa, wydaje mi się, że ma coraz większe pragnienie. Oby zdrowie mu dopisywato.

Wyekscerpowana leksyka pozwala wskazać dominujące pola tematyczne w obrębie zagadnienia. Pierwszym z nich jest terminologia medyczna, związana ze zdrowiem, z choroba lub leczeniem samochodu (przymiotniki: zdrowy, chory; rzeczowniki: zdrowie, choroba, dolegliwości, zadyszka, staba kondycja; czasowniki: boleć, chorować, reanimować, kaszleć, brakować tchu). Kolejny wyodrębniony zakres to określenia związane z jedzeniem i piciem, w szerszym kontekście uznane za czynności fizjologiczne człowieka (np. czasowniki jeść, pić, smakować, żłopać; wyrażenia: mieć apetyt, mieć pragnienie). Trzecia grupa leksemów odnosi się do określeń łączonych ze zmęczeniem i z używaniem przemocy wobec pojazdu: przymiotniki umęczony, zmęczony; czasownik katować.

Należy również postawić pytanie o przyczynę i zasadność używania takich wyrażeń w odniesieniu do pojazdu. Uczniowie z pewnością wskażą tu przede wszystkim emocjonalny stosunek do samochodu i traktowanie go jak żywej osoby. 
Zadanie 3. Określenia marek i modeli pojazdów. Kolejnym przykładem związanym z kategorią wartościowania oraz derywacją rzeczowników mogą być używane w socjolekcie nazwy marek i modeli pojazdów. Określenia nimi inspirowane stanowią rozbudowaną grupę leksemów w języku miłośników motoryzacji. Ich popularność zależy od rozpoznawalności danej marki, jej nazwy i liczby samochodów na rynku. W bogactwie określeń można zaobserwować różne tendencje nazewnicze - kilka z nich będzie przedmiotem tego ćwiczenia. Dzięki niemu uczeń może wykształcić umiejętność klasyfikacji derywatów, dostrzegania mechanizmów tworzenia leksyki oraz wskazywania formantów i nazywania ich funkcji.

Podstawą zadania może być zbiór wyrazów bazowych, które należy podzielić na grupy, zgodnie z podanym wzorem (zob. tabelę 2.).

Tabela 2.

Określenia marek i modeli pojazdów

\begin{tabular}{|l|l|}
\hline $\begin{array}{l}\text { Określenia z formantami } \\
\text { sufiksalnymi }\end{array}$ & $\begin{array}{l}\text { Formant ...... } \\
\text { Formant ...... } \\
\text { Formant ...... }\end{array}$ \\
\hline $\begin{array}{l}\text { Spolszczenia (zgodnie z polską } \\
\text { fonetyką) }\end{array}$ & \\
\hline $\begin{array}{l}\text { Wyrazy nawiązujące do kraju } \\
\text { produkcji }\end{array}$ & $\begin{array}{l}\text { Leksemy do wykorzystania: opelek }{ }^{21}, \text { porsze, reno, włoch, fordzik, bmka, hondka, francuz, } \\
\text { korsa, golfik, skośnooki, nissanek, kija, niemiec, peżo, audik, beemwu, koreańczyk, seacik, } \\
\text { tojota, japończyk }\end{array}$ \\
\hline
\end{tabular}

Część zadania (trudniejszą) może stanowić podawanie prawidłowej nazwy marki/modelu (w wersji łatwiejszej — ze względu na zapis ortograficzny uczniowie mogą otrzymać karteczki z poszczególnymi markami/modelami). W tym przypadku uczniowie dodatkowo będą sami przytaczać/wymyślać popularne określenia samochodów, wpisujące się w podane kategorie. Ważnym aspektem rozwiązania zadania będzie omówienie wypełnionej tabeli, wskazanie formantów (-ik, -ek, -uś, -ak) i ich funkcji (funkcja zdrabniająca, spieszczająca - wyrażenie emocjonalnego stosunku do pojazdu lub jego niewielkich rozmiarów; $-k a$ - formant wprowadzający formę żeńską). Należy także zwrócić uwagę na leksemy dostosowane do polskiej fonetyki, odzwierciedlające po-

${ }^{21}$ Zapis określeń marek i modeli pojazdów małą literą został ustalony na podstawie analizy treści portali motoryzacyjnych i liczebnej przewagi takich form zapisu (z uwagi na potoczne użycie danych form). Zwracam jednak uwagę na niejednolitość sposobu zapisywania omawianych wyrazów. Zgodnie z normą słownikową wyroby zapisujemy małą literą, a nazwy marek — wielką. Zob. Poradnik językowy. Piszemy poprawnie. Oprac. E. Polański. Warszawa 2008, s. 142, $146-147$. 
pularną tendencję do zapisywania wyrazów w sposób, w jaki się je wymawia. Weryfikacja leksemu z prawidłowym zapisem nazwy marki/modelu pojazdu wskaże różnice między nimi i może być przyczynkiem do rozmowy na temat spolszczania nazw. Ostatnia grupa nazw, odnosząca się do miejsca produkcji danej marki, bezpośrednio koreluje z poprzednim zadaniem, pełniąc funkcję nadawania pojazdom cech ludzkich (Francuz — mieszkaniec Francji, francuz — samochód wyprodukowany w tym kraju). Wzbogaceniem tabeli mogłoby być podawanie innych marek/modeli samochodów (istniejących określeń lub neologizmów).

\section{Podsumowanie}

Podsumowaniem lekcji może być rozmowa z uczniami o celach stosowania wymienionych w ćwiczeniach zabiegów (tj. leksemów wartościujących, zdrobnień i spieszczeń, animizacji i antropomorfizacji) wobec pojazdu. Wśród nich można wskazać między innymi: emocjonalny stosunek właściciela do samochodu, okazywanie uczuć wobec pojazdu, budowanie wspólnoty kierowcy i samochodu, dbałość o pojazd i jego stan techniczny oraz werbalizowanie pasji motoryzacyjnej. Warto w tym miejscu zwrócić także uwagę na inne wykładniki wyrażania rangi pojazdu w życiu jego użytkownika, np.:

- bezpośrednie zwroty do samochodu: formy na ty, używanie form $m y$ inkluzywnego (budowanie poczucia wspólnoty z pojazdem — jedziemy, ruszamy itp.);

- nazywanie samochodu za pomocą pieszczotliwych i zdrobniałych określeń;

- nadawania pojazdowi imienia (także systemowi nawigacji GPS).

Zaprezentowany materiał może posłużyć za podstawę zadania domowego. Po zapoznaniu się na lekcji z pewną odmianą języka środowiskowego, jaką jest socjolekt miłośników motoryzacji, uczniowie poradzą sobie w domu z napisaniem opowiadania z dialogiem. Mogliby w nim wykorzystać 20 leksemów, które poznali na lekcji, oraz 5 nowych określeń (inne znane określenia samochodu wyszukane na forach motoryzacyjnych, w reklamach itp.) z omawianego socjolektu.

Przedstawiona propozycja dydaktyczna zawiera przykładowe zadania do realizacji podczas lekcji na temat języków środowiskowych. Zdobywana w ten sposób wiedza może rozwijać w uczniu świadomość różnorodności odmian językowych współczesnej polszczyzny, a także uzmysławiać rolę socjolektu w grupotwórczej funkcji danej społeczności.

Tematyka motoryzacyjna, ze względu na codzienny z nią kontakt: w reklamach, treściach zamieszczanych w Internecie (np. na forach dla miłośników 
motoryzacji) oraz tendencję do rozbudowy pola leksykalnego z tego zakresu, staje się ciekawym obszarem eksploracji leksyki środowiskowej — także w sytuacjach dydaktycznych.

\section{Aneks}

Załącznik do zadania 1.

Tabela 3.

Pozytywne, negatywne i neutralne nazwy pojazdów - rozwiązanie ${ }^{22}$

\begin{tabular}{|c|c|c|}
\hline Określenia pozytywne & Określenia negatywne & Określenia neutralne \\
\hline $\begin{array}{l}\text { auteczko, bryka, cacko, fura, } \\
\text { limuzyna, maleństwo, peretka, } \\
\text { rakieta, rumak, skarb, strzata, } \\
\text { ślicznotka, wehikut }\end{array}$ & $\begin{array}{l}\text { śmietnik, dziad, gniot, grat, } \\
\text { gruchot, kanciak, kloc, ru- } \\
\text { pieć, skarbonka, staroć, } \\
\text { wyrób samochodopodobny, } \\
\text { zamulacz, zdechlak, złom }\end{array}$ & auto, cztery kótka, egzemplarz \\
\hline
\end{tabular}

Załącznik do zadania 3.

Tabela 4.

Określenia marek i modeli pojazdów — rozwiązanie (wraz z podaniem nazwy)

\begin{tabular}{|l|l|}
\hline $\begin{array}{l}\text { Określenia z formantami } \\
\text { sufiksalnymi }\end{array}$ & $\begin{array}{l}\text { Formant -ek: nissanek (marka Nissan); opelek (marka Opel) } \\
\text { Formant -ik: audik (marka Audi); fordzik (marka Ford); golfik (mo- } \\
\text { del Golf, marka Volkswagen); seacik (marka Seat) } \\
\text { Formant -ka: beemka (marka BMW); hondka (marka Honda). }\end{array}$ \\
\hline $\begin{array}{l}\text { Spolszczenia (zgodnie } \\
\text { z polską fonetyką) }\end{array}$ & $\begin{array}{l}\text { beemwu (marka BMW); kija (marka Kia); korsa (model Corsa, } \\
\text { marka Opel); porsze (marka Porsche); reno (marka Renault); peżo } \\
\text { (marka Peugeot); tojota (marka Toyota) }\end{array}$ \\
\hline $\begin{array}{l}\text { Wyrazy nawiązujące do do } \\
\text { kraju produkcji }\end{array}$ & $\begin{array}{l}\text { francuz (np. marki Renault, Peugeot); japończyk (np. marka Toyo- } \\
\text { ta, Honda); koreańczyk (np. marka Kia); niemiec (np. marki BMW, } \\
\text { Opel); skośnooki (marki azjatyckie - np. Kia, Toyota); włoch (np. } \\
\text { marka Alfa Romeo) }\end{array}$ \\
\hline
\end{tabular}

${ }^{22}$ Przynależność wyrazów do poszczególnych grup została podyktowana częstotliwością kontekstowego występowania określeń na portalach motoryzacyjnych i jest wynikiem przeprowadzonej analizy. Należy jednak pamiętać o wspomnianej już możliwości sytuacyjnego wartościowania niektórych określeń i możliwości ich klasyfikacji jako zarówno leksemów pozytywnych, jak i negatywnych. 


\section{Bibliografia}

Grabias S.: Język w zachowaniach społecznych. Lublin 1997.

Kołodziejek E.: Społeczne i kulturowe uwarunkowania wspótczesnych odmian zawodowych (na przykładzie profesjolektów marynarzy, żolnierzy i policjantów). W: Polskie języki. O językach zawodowych i środowiskowych. Red. M. Milewska-Stawiany, E. Rogowska-Cybulska. Gdańsk 2010.

Kow alikow a J.: Jak się mówi i pisze w szkole? Szkic do pejzażu dydaktycznego szkolnych odmian językowych. W: Odmiany polszczyzny w szkole. Teoria i praktyka. Red. H. Synowiec. Współudział M. Kubarek. Katowice 2013.

Piek ot T.: Język w grupie spolecznej. Wprowadzenie do analizy socjolektu. Wałbrzych 2008.

Podstawa programowa ksztatcenia ogólnego dla przedszkoli i szkót podstawowych z komentarzem. https://www.ore.edu.pl/wp-content/uploads/2017/05/jezyk-polski.-pp-z-komentarzem.-szkola -podstawowa.pdf [data dostępu: 26.02.2019].

Poradnik językowy. Piszemy poprawnie. Oprac. E. Polański. Warszawa 2008.

Przybylska R.: Wprowadzenie do nauki o języku polskim. Podręcznik dla szkół wyższych. Kraków 2003.

Szczepaniak C.: Zrozumieć samochód. Samochód bez tajemnic. Łódź 2011.

Wilczek W.: Polski język motoryzacyjny poczatku XXI wieku (na materiale portali hobbystycznych). Katowice 2016.

Wileczek A.: Kod młodości. Młodomowa w aspektach społeczno-kulturowych. Warszawa 2018.

Wilkoń A.: Typologia odmian językowych współczesnej polszczyzny. Katowice 2000.

\section{Strony internetowe}

http://www.bikeforum.pl/topic/31834-czy-jest-sens-wymieniac-rame-a-moze-tylko-mostek-xc-ala -szybka-hybryda-enduro/ [data dostępu: 3.03.2019].

http://swiatpilki.com/viewtopic.php? $\mathrm{f}=8 \& \mathrm{t}=20692 \&$ start=45 [data dostępu: 3.03.2019]. http:// swiatpilki.com/viewtopic.php? $\mathrm{f}=8 \& \mathrm{t}=20692 \&$ start $=90$ [data dostępu: 3.03 .2019 ].

https://www.dogomania.com/forum/topic/27154-jak\%C4\%85-ras\%C4\%99-mam-wybra\% $\% 4 \% 87$

-vol-2/?page $=607$ [data dostępu: 3.03.2019].

http://www.e-gory.pl/forum/viewtopic.php?f=17\&t=2178 [data dostępu: 3.03 .2019 ].

https://lowcygier.pl/forum/viewtopic.php?f=11\&t=17112 [data dostępu: 3.03.2019]. 